\title{
Correction to: A new species of Microterys (Hymenoptera: Encyrtidae) from Northeast China, parasitoid of Parthenolecanium corni (Bouché) (Hemiptera: Coccidae)
}

\author{
Guo-Hao Zu • Cheng-De Li • Yuan-Hong Wang
}

Published online: 26 March 2019

(C) Springer Nature B.V. 2019

Correction to: Phytoparasitica (2018) 46, 671-675

https://doi.org/10.1007/s12600-018-0691-5

\section{Correction}

In a paper describing Microterys angustus $\mathrm{Zu}, \mathrm{Li} \&$ Wang sp. nov. ( $\mathrm{Zu}$ et al. 2018), the authors omitted to designate the depository of the holotype. Under Article 16.4.2 of the current International Code of Zoological Nomenclature (1999) this renders the name unavailable because the name and location of the depositor of the primary type must be designated.

Microterys angustus $\mathrm{Zu}, \mathrm{Li} \&$ Wang sp. nov.in $\mathrm{Zu}$ et al. (2018)

"Holotype. f\# [on slide], China, Heilongjiang Province, Harbin City, Zhengyi Road, 10. V. 2015, Yan Gao (NEFU), reared from Parthenolecanium corni (Bouché) on Acer saccharum Marsh." Holotype deposited in the insect collections of Northeast Forestry University,

The online version of the original article can be found at https://doi.org/10.1007/s12600-018-0691-5

G.-H. Zu • Y.-H. Wang

College of Horticulture and Landscape, Tianjin Agricultural

University, Tianjin 300384, China

G.-H. Zu

e-mail: zuguohao@tjau.edu.cn

C.-D. Li $(\bowtie)$

School of Forestry, Northeast Forestry University, Harbin 150040, China

e-mail: lichengde0608@sina.com
Harbin, 150040, China. The species is described in full and compared with related species in $\mathrm{Zu}$ et al. (2018).

\section{References}

International Commission on Zoological Nomenclature (1999). International Code of Zoological Nomenclature. Fourth Edition. London, UK: The International Trust for Zoological Nomenclature 1999.

Zu, G. H., Li, C. D., Wang, Y. H. (2018). A new species of Microterys (Hymenoptera: Encyrtidae) from Northeast China, parasitoid of Parthenolecanium corni (Bouché) (Hemiptera: Coccidae). Phytoparasitica, 46: 671-675.

Publisher's Note Springer Nature remains neutral with regard to jurisdictional claims in published maps and institutional affiliations. 